\title{
Evaluation of a Medical Residency Program in Gynecology and Obstetrics
}

\section{Avaliação de um Programa de Residência Médica em Ginecologia e Obstetrícia}

\section{KEYWORDS}

- Medical Education.

- Internship and Residency.

- Educational Assessment.

- Gynecology.

- Obstetrics.
Natalia Romano Sanchez $z^{1}$ D Cibele Isaac Saad Rodrigues ${ }^{\mathrm{I}}$ (D)

\begin{abstract}
Introduction: Medical residency in gynecology and obstetrics is unquestionably important in the training of physicians who choose this specialty of the Brazilian Ministries of Health and Education. However, studies evaluating these residency programs are scarce, especially regarding the reflexive qualitative aspects of the research. Therefore, this exploratory and descriptive study aimed to evaluate the current medical residency program in gynecology and obstetrics of the School of Medical and Health Sciences at Pontifícia Universidade Católica de São Paulo (PUC-SP) using a quantitative and qualitative approach. Method:The methodology included a comparative curriculum analysis between the program recommended by the National Committee of Medical Residency until 2018 and the program offered by PUC-SP School of Medical and Health Sciences, as well as a selfadministered questionnaire completed by individuals who graduated between 2007 and 2018. Results: The most significant findings of the comparative curriculum analysis include discrepancies in the percentage arrangement of annual workload, indicating an overload of on-call duty hours, and unequal distribution of internships. The questionnaire response rate was $66 \%$ (41 of 62 participants). Most respondents were women ( $n=32,78 \%)$, who worked mainly in the cities of Sorocaba $(n=21,43.7 \%)$ and São Paulo $(n=10,21 \%)$. Most medical graduates were partially satisfied with the program $(n=34,82.9 \%)$. Some responses also matched the findings of the comparative curriculum analysis, such as dissatisfaction with the number of gynecological surgical procedures performed ( $n=39,95.1 \%)$. Regarding the content analysis of open-ended answers, categorized according to Bardin, the graduates appreciated activities in obstetrics, and the most relevant criticisms were related to fewer hours assigned to certain activities, especially those devoted to gynecological surgical practices and theoretical activities. Conclusions: Based on the findings, suggestions were proposed and accepted by the managers for changes that should have a positive impact on the medical residency program. This research contributes to the diagnostic evaluation of a traditional medical residency program in Brazil, proposes improvements, and uses reproducible methods, thus serving as a comparison basis for other studies so that advances can be made in the training of these specialists.
\end{abstract}




\section{PALAVRAS-CHAVE}

- Educação Médica.

- Internato e Residência.

- Avaliação Educacional.

- Ginecologia.

- Obstetrícia.

\section{RESUMO}

Introdução: A residência médica em ginecologia e obstetrícia é indiscutivelmente importante para a capacitação dos médicos que optam por essa especialidade dos Ministérios da Saúde e da Educação. Entretanto, as pesquisas que avaliaram esses programas de residência são escassas, especialmente no que tange a aspectos reflexivos qualitativos. Assim, este estudo descritivo e exploratório, com abordagem quantitativa e qualitativa, buscou avaliar o programa atual de residência médica em ginecologia e obstetrícia da Faculdade de Ciências Médicas e da Saúde (FCMS) da Pontifícia Universidade Católica de São Paulo (PUC-SP). Método: Como metodologia, utilizou-se a análise curricular comparativa entre o programa preconizado pela Comissão Nacional de Residência Médica até 2018 e o programa oferecido pela FCMS da PUC-SP, além de questionários autoaplicáveis a egressos do período de 2007 a 2018. Resultados: Entre os achados mais importantes da análise curricular comparativa, estão divergências sobre a disposição percentual de carga horária anual, evidenciando sobrecarga em horas de plantão, e a distribuição não equilibrada de estágios. A taxa de retorno do questionário foi de $66 \%$ (41 dos 62 participantes). A maioria dos respondentes era do gênero feminino ( $n=32,78 \%)$, com atividade predominante nas cidades de Sorocaba $(n=21,43,7 \%)$ e São Paulo $(n=10,21 \%)$. Houve preponderância de satisfação parcial do egresso com o programa cursado $(n=34,82,9 \%)$. Também foram observadas respostas que condizem com os achados da análise curricular comparativa, como a insatisfação com o número de procedimentos cirúrgicos ginecológicos realizados $(n=39,95,1 \%)$. Em relação à análise de conteúdo das questões discursivas, categorizadas segundo Bardin, houve valorização das atividades em obstetrícia pelos egressos, e as críticas mais evidentes foram relacionadas à menor quantidade de horas para certas atividades, em especial àquelas dedicadas às práticas cirúrgicas ginecológicas e atividades teóricas. Conclusões: Com base nos achados, foram propostas e acatadas pelos gestores sugestões de mudanças que devem trazer impacto positivo ao programa da residência médica. Esta pesquisa contribui para a avaliação diagnóstica de um tradicional programa de residência médica, propõe melhorias e utiliza metodologia reprodutível, podendo, assim, servir de comparação para outros estudos, de modo que avanços possam ser estabelecidos na formação do especialista.

Received on $01 / 18 / 20$

Accepted on $02 / 05 / 20$

\section{INTRODUCTION}

Medical residency (MR) is a postgraduate teaching modality aimed at training in supervised service in a specific medical area. The history of MR in Brazil had an irregular start, characterized by the creation of programs without standardization, exclusively meeting the needs of each institution and service. ${ }^{1}$ Following the movement of rights by resident physicians, the actions of the National Association of Resident Physicians (Associação Nacional de Médicos Residentes) and Brazilian Association of Medical Education (Associação Brasileira de Educação Médica) stand out, which played an essential role in the fight for the standardization and control of MR programs. ${ }^{2,3}$

With the creation of the National Medical Residency Commission (CNRM, Comissão Nacional de Residência Médica) in $1977^{4}$, residents started to be legislated, benefits were introduced in addition to fundamental labor rights. ${ }^{4,5}$ Law n. 6.9326 defined MR as the medical teaching modality that grants a specialist title in the medical area to the graduates of a program, acknowledged throughout the national territory. ${ }^{6}$

Currently, MR is considered a "gold standard" for lato sensu medical specialization. ${ }^{3,7}$ The regulation and supervision of these programs are coordinated by several hierarchical bodies, which are part of the Ministry of Education and Culture (MEC, Ministério da Educação e Cultura). ${ }^{3}$ For a program to be accredited in the CNRM, it must meet all necessary prerequisites, including a supervisor and a group of tutors under their coordination for the development of activities. ${ }^{4,7}$

The perception of the need to make changes in professional training to improve the Unified Health System (SUS) ${ }^{8}$ considered Gynecology and Obstetrics (GO) as one of the strategic programs ${ }^{8}$. Currently, in Brazil, GO is a basic area of knowledge and its Residency Program (GOMRP) has direct access and lasts 3 years. ${ }^{4}$ According to analyzes of distribution of MR programs in the country ${ }^{9,10}$, in 2011, more than half of GOMRP (54.7\%) are located in the Southeast Region ${ }^{9,10}$. According to data provided by the MEC General Coordination of Health Residencies in $2017^{11}$, there were, in the first semester of 2017, 93 GORMP accredited by CNRM, corresponding to 298 openings.

Historically, the MR in GO of the School of Medical and Health Sciences (FCMS, Faculdade de Ciências Médicas e da Saúde) of Pontifícia Universidade Católica de São Paulo (PUC-SP) started in 1972. After regulation and accreditation by CNRM in 1977, the Program received periodic approval according to the legislation ${ }^{12}$ and, since its creation, until December 2018, 283 specialists were trained, currently having 08 accredited annual openings.

Despite the numerous positive aspects that MR can offer, it was possible to experience the reality that is sometimes distressing, stressful and even unsatisfactory in the face of expectations and anxieties in relation to the acquisition of knowledge, development of skills and attitudes in the course of daily practice. Therefore, this study aimed to evaluate, from the point of view of the medical graduates, the GOMRP of FCMS of PUC-SP and to compare it, in practice, with that recommended by the CNRM, in addition to assessing the graduates' profile, identifying and evaluating whether the program met their expectations.

REVISTA BRASILEIRA DE EDUCAÇÃO MÉDICA

2 44 (2) : e057; 2020 


\section{MATERIAL AND METHODS}

This is a descriptive and exploratory study with a quantitative and qualitative approach, the result of a professional master's degree in Education in Health Professions of FCMS of PUC-SP. It consisted of two stages: comparative document analysis and questionnaire application. The comparative document analysis was carried out between the GOMRP proposed by MEC, according to the minimum prerequisites stipulated in CNRM resolution $2 / 2006^{12}$, with that offered by COREME of FCMS of PUC$\mathrm{SP}^{13}$ in 2017. To compare the workload between programs, it was decided to calculate the number of hours worked by the residents of GOMRP of FCMS of PUC-SP ${ }^{13}$ during the year 2017. In that year, the program had a total of 20 residents, being 08 in the first year (R1), 05 in the second (R2) and 07 in the third (R3) year. The mean number of hours by the number of resident physicians was calculated for each year of training.

To calculate the total hours, the mean was taken of the hours dedicated by residents of each year. To compare the percentage of hours dedicated to each activity, by year of residency, the mean number of hours were calculated for each of the activities in the schedule and their percentage was stipulated in relation to the total mean hours worked in the year. To facilitate the comparison between percentages, the number found was rounded up to absolute values, as presented by the program proposed by MEC.

To obtain significant data regarding the studied GOMRP, it was decided to select, from the total of 283 GOMRP graduates of FCMS PUC-SP from the residency program creation until 2018, the 62 possible participants who completed the program between 2007 and 2018 . To meet the selection criteria and to avoid possible selection bias, the researcher was excluded from the sample. The discontinuity criterion was applied to participants who withdrew from this study at any time, and all those who agreed to participate signed the Free and Informed Consent (FIC) form, guaranteeing the confidentiality of their identities.

The main theme of the questionnaire was the impressions and evaluations of the GOMRP made by the graduates, totaling 40 closed and open questions, 28 on the main theme and 12 aimed at sociodemographic characterization. During the creation and before being applied, the questionnaire underwent orthographic and semantic analysis performed by a specialized professional. A pre-test was made available for suggestions and criticisms to three GO teachers (experts) from the same institution and to ten graduates not included in the research. The questionnaire was made available only after approval by the Research Ethics Committee and after the suggested corrections and agreed in the pre-test were performed.

The questionnaire was made available for 56 days on the GoogleForms platform. All selected participants received email notifications, cell phone messages weekly, and telephone contact in the last week. A total of 41 individuals participated in the research, with a response rate of $66 \%$, both considered of adequate sizes to guarantee the research statistical validity. ${ }^{14}$

For quantitative analysis of sociodemographic data, the program Stata $13.1^{\oplus}$ was used and for the crossing the data of closed responses the analysis software, chi-square tests and Fisher's exact test were used.

As for the discursive questions, the content analysis proposed by Bardin was used. ${ }^{15,16}$ As recommended by this qualitative analysis technique, after the initial reading, all material was transcribed in full and extensively read for coding and transforming the content into recorded units. For a single question, several initial subcategories could be present. Therefore, despite 41 respondents, it was possible to obtain more than 41 different subcategories that were grouped and described in valid, objective, consistent and pertinent categories. Finally, a reflexive interpretation of the findings was performed. The participants were listed according to the chronological order in which responses were sent, which made it possible to demonstrate some results in this work, maintaining the anonymity guaranteed in the FIC form.

\section{RESULTS AND DISCUSSION}

Document and comparative analysis

According to CNRM resolution $2 / 2006^{12}$, a matrix of programmatic content was developed for each specialty of $\mathrm{MR}^{17}$. This Program was analyzed in comparison with the Internal Rules of the GOMRP of FCMSPUCSP $^{13}$ in its most current version. The proposed Program highlights the main objective to be achieved in the training of the resident physician in GO at the end of the programmatic course and its specific objectives. It covers the theoretical and practical activities in detail and their respective percentages to be dedicated in each year of residency. The document also recommends evaluation processes and sets out the minimum requirements to be offered.

In the section on the theoretical contents of the proposed Program, there is a description of the general and specific topics of greatest relevance to be addressed. Moreover, several topics are suggested for updating, as well as courses and other theoretical activities that the learner can carry out. In the section dedicated to each year of the residency, the document establishes the skills to be developed, demonstrating at the end, in a table, the percentage of hours to be used for each training. It is important to emphasize that there are no large numerical discrepancies in the division of hours dedicated to activities during all years.

In the first year of residency, the focus is on low-risk care, encompassing knowledge on primary prevention of gynecological diseases and promotion of women's health, in addition to normal pregnancypuerperal physiology, lactation and puerperal family planning. During $\mathrm{R} 2$, the focus of learning is the development of the GO sub-areas, with activities in specialized outpatient clinics and surgeries, beginning their training in gynecological oncology and in high-risk obstetrics. The largest percentage of time during the R3 year is devoted to the surgical room, in the training of more complex surgeries and in specialized gynecology outpatient clinics.

The FCMS-PUCSP document is more objective and practical, emphasizing important communications for the monitoring and training the resident throughout the year, such as appropriate clothing and documents necessary for certain procedures, such as surgical scheduling Especially for residents from other higher education institutions, unfamiliar with the service's routines, it is important they receive these guidelines that facilitate their integration. The structure of the available woman's care sectors and services comprise all the prerequisites required by CNRM for their accreditation.

It can be observed that the FCMS regulation of PUC-SP does not emphasize the knowledge and technique to be acquired by the residents at the end of their training, showing only as the final result of the training the possibility of acquiring the completion certificate, without emphasizing the pedagogical objective, which is the guarantee of knowledge, skills and appropriate attitudes to work in the specialty. It is possible to observe a

REVISTA BRASILEIRA DE EDUCAÇ̃̃o MÉDICA

3 44 (2) : e057; 2020 
certain hierarchical weight in the residents' functions, in which the R2 must "supervise the activities" of the R1 and interns during medical care. The R3, on the other hand, has the function of "clearing up doubts" of other physicians and academics. Therefore, there is a certain attenuation of the teacher/preceptor's role in these functions. The document allows the resident to behave as and be, in practice, the preceptor of the younger residents, without considering the importance of qualified supervision.

In the GOMRP of PUC-SP, the residents themselves participate in the organization of their schedules, mainly related to the on-duty schedule. Although the residents' role in these activities should be valued, as it makes them an integral and active part of the process of building their teaching and learning, it must be recalled that the area supervisor, together with COREME, is the only legal professional responsible for the accomplishment of the activities necessary for the residents' training, always based on CNRM Resolution $2 / 2006^{12}$ or another that may replace it, and the content proposal offered. ${ }^{13}$

This same Resolution ${ }^{12}$ leaves at the discretion of the COREME of each institution to choose the residents' evaluation method, whether oral, written, practical or performance tests per scale of attitudes, respecting the minimum quarterly frequency. The COREME at PUC-SP chose to evaluate the resident according to their attitudinal performance, including analysis of presentations at scientific meetings and activity frequency. However, there is no detailing of the instrument to be used, which places the institution in disagreement with what is recommended and provides a clear opportunity for improvement.

It is important to note that diversified assessment methods applied to the different actors involved in the teaching and learning process can provide different elements, which, together, provide a better perception of the cognitive, affective and psychomotor skills of those being assessed and those who are assessing. Peer-assessment of residents, self-assessment and feedback in this process are crucial for correcting directions. ${ }^{18}$

There is no mention of any type of evaluation of teachers/ preceptors in both analyzed documents. This demonstrates a lack of formal recognition of this activity, which is increasingly important for professional training. It is necessary to invest in pedagogical training and education for the educator who works directly with resident physicians. We must recognize the importance of this role as an educator as a strategy to improve residency programs, culminating in better medical care and patient well-being. ${ }^{19}$

\section{Workload and activity arrangement}

Law number $6,932 / 81^{6}$ establishes an annual workload of 2,880 hours, distributed within a limit of 60 hours per week, including 24 hours on duty. Based on it, the CNRM suggests a differentiated workload distribution for each year of residency, according to the degree of complexity of each required activity. The comparison between workload and activity arrangement is illustrated in Graphs 1 and 2.

A drastic difference is perceived between the workload of the three years (Graph 1). When comparing the arrangement of R1 activities (Graph 2), it is clear there is an excessive number of hours dedicated to on-duty activities. In 2017, R1 completed an on-duty workload that was almost four times that recommended by CNRM. This is undoubtedly the most divergent activity in the comparison. There is also an important contrast in the activity "General and Ambulatory Surgical Center".
There are activities contemplated by the FCMS residency program at PUC-SP that are not included in the activities proposed for R1 by CNRM, such as "Distance Learning (DL)". This encompasses the practice of studying at home or using resources offered at the institution's library on specific illnesses, assigned to the residents by their supervisor, aiming to standardize and update care protocols for services that are internships areas in the program. This need resulted from failures observed by the preceptors and teachers in the standardization of conducts and protocols for medical care in SUS woman's care service, linked to the institution. This is a factor that hinders the learning of resident physicians, as it makes them subject to important variations in conducts without discussing the scientific basis for the different therapeutic options.

For R2 (Graph 2), there was again an overload of on-duty shifts, in addition to the higher percentage of hours allocated to the "Obstetric Center". It is also evident the contrast in the workload that is below the necessary for the practice in the "Specialized Ambulatory and Inpatient Unit: Gynecology". This activity is important to create the theoreticalpractical background on several gynecological diseases, essential for the differential diagnosis and adequate follow-up for each patient, according to their particularities. It is possible to observe a lower workload for "Urgency/Emergency"; however, it is understood that the objectives of this activity are achieved during the on-duty skills in GO.

In the comparison of activities for $\mathrm{R} 3$, there is an important reduction in the number of hours on duty, even though it remained above the percentage proposed by CNRM (Graph 2). The low percentages for outpatient clinics specialized in GO, also present in previous years, remain evident in R3. A possible justification would be the reduced availability of hours for specialized outpatient clinics, especially in the gynecology area. There is a probability for the resident to learn and develop skills in the several specific sub-areas, but the frequency is low. Another important contrast is in the "operating room" activity, which does not reach the expected workload. One of the possible factors, and probably the one with the highest impact, is the insufficiency of material, structural and human resources to supply the required demand, both for the service and for the program.

\section{Graph 1}

Workload completed in 2017 in the RM program in GO of PUC-SP

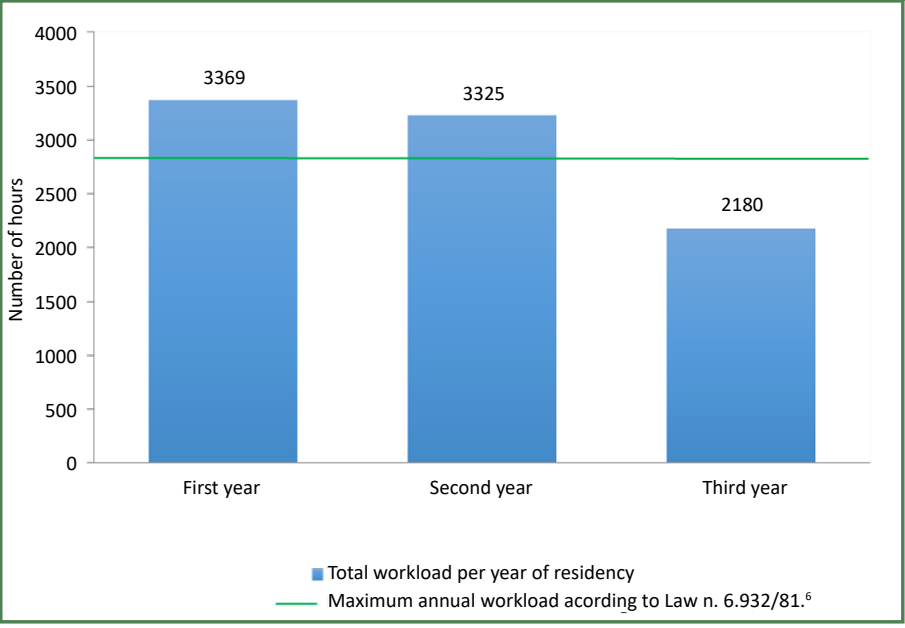

Source: Study data. The author.

Workload completed by residents in Gynecology and Obstetrics at FCMS of PUCSP, in 2017. The line represents the workload limit stipulated by Law N. $6.932 / 81^{6}$. 
A difference in the comparative of R3, which offers positive aspects to the institution, is the resident's opportunity to acquire experience in an optional internship in the several services and universities associated with the institution, also allowing the resident to acquire a new bond

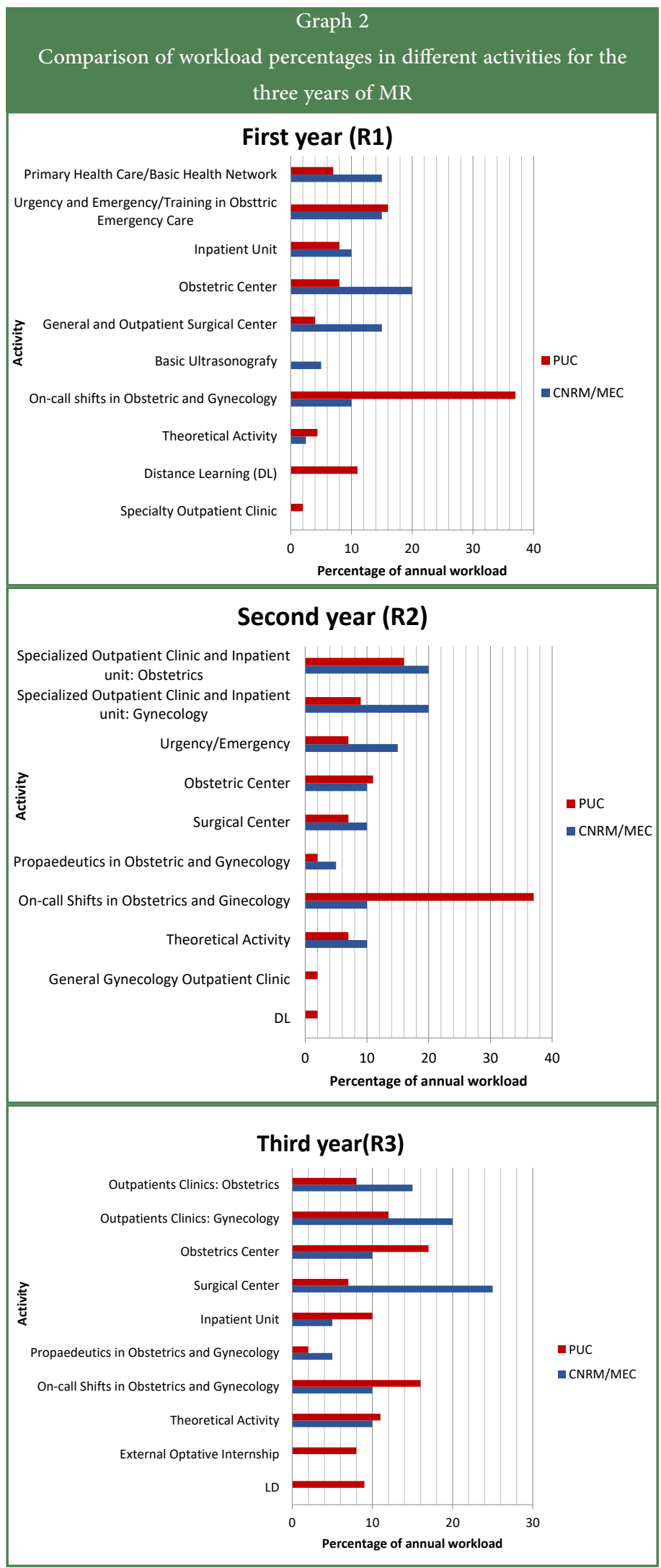

with the service, either national or international. This advantage makes it possible to improve knowledge of resident physicians' personal interest in a subspecialty, expanding their horizons and helping to stimulate study and research as previously demonstrated in other residency programs. ${ }^{20}$

\section{Questionnaire}

Women $(\mathrm{n}=32,78 \%)$, aged between 28 and 34 years $(\mathrm{n}=27,65.8 \%)$, white $(\mathrm{n}=37,90.2 \%)$, with the specialty as an academic degree $(\mathrm{n}=36$, $87.8 \%)$ and working in a private hospital $(\mathrm{n}=36,87.8 \%)$, were the main characteristics of the respondents. The other sociodemographic findings are shown in Table 1.

The questions regarding satisfaction and dissatisfaction with the attended program showed that $82.9 \%(\mathrm{n}=34)$ were partially satisfied, showing that there are problems to be overcome. Table 2 shows the

\begin{tabular}{|c|c|c|}
\hline \multicolumn{3}{|c|}{$\begin{array}{ll}\text { Table } 1 & \end{array}$} \\
\hline Characteristic & $\mathbf{N}$ & $\%$ \\
\hline \multicolumn{3}{|l|}{ Gender } \\
\hline Female & 32 & 78 \\
\hline Male & 9 & 22 \\
\hline \multicolumn{3}{|l|}{ Age } \\
\hline $28-34$ & 27 & 65,8 \\
\hline $35-41$ & 14 & 34,2 \\
\hline \multicolumn{3}{|l|}{ Marital Status } \\
\hline Married & 23 & 56 \\
\hline Single & 14 & 34,2 \\
\hline Common-law marriage & 4 & 9,8 \\
\hline \multicolumn{3}{|l|}{ Ethnicity } \\
\hline Caucasian & 37 & 90,2 \\
\hline Mixed-race & 2 & 4,9 \\
\hline Asian & 2 & 4,9 \\
\hline \multicolumn{3}{|l|}{ Nationality } \\
\hline Brazilian & 40 & 97,6 \\
\hline Foreigner & 1 & 2,4 \\
\hline \multicolumn{3}{|l|}{ Number of children } \\
\hline 0 & 24 & 58,5 \\
\hline 1 & 8 & 19,5 \\
\hline 2 & 9 & 22 \\
\hline \multicolumn{3}{|l|}{ Year of Medical School Graduation } \\
\hline $2002-2010$ & 21 & 51,2 \\
\hline $2011-2014$ & 20 & 48,8 \\
\hline \multicolumn{3}{|l|}{ Medical School graduated from } \\
\hline PUC-SP & 18 & 43,9 \\
\hline $\begin{array}{l}\text { Other Universities in the state of } \\
\text { São Paulo }\end{array}$ & 11 & 26,8 \\
\hline Other Universities in Brazil & 12 & 29,3 \\
\hline
\end{tabular}




\begin{tabular}{|c|c|c|}
\hline \multicolumn{3}{|c|}{ Table 1} \\
\hline Characteristic & $\mathbf{N}$ & $\%$ \\
\hline \multicolumn{3}{|l|}{ City of work } \\
\hline Sorocaba & 21 & 51,2 \\
\hline São Paulo & 10 & 24,4 \\
\hline Other cities in Brazil & 10 & 24,4 \\
\hline \multicolumn{3}{|l|}{ Academic Degree } \\
\hline Specialist physician & 36 & 87,8 \\
\hline Latu Sensu Postgraduate Degree & 4 & 9,8 \\
\hline Master's Degree & 1 & 2,4 \\
\hline \multicolumn{3}{|l|}{ Personal Income } \\
\hline $\mathrm{R} \$ 5$ mil $-\mathrm{R} \$ 15 \mathrm{mil}$ & 20 & 48,8 \\
\hline $\mathrm{R} \$ 15 \mathrm{mil}-\mathrm{R} \$ 25 \mathrm{mil}$ & 14 & 34,2 \\
\hline $\mathrm{R} \$ 25$ mil ou mais & 7 & 17 \\
\hline \multicolumn{3}{|l|}{ Work Activity } \\
\hline Private Hospital & 36 & 87,8 \\
\hline Private Clinic & 27 & 65,9 \\
\hline Health Insurance Outpatient Clinic & 26 & 63,4 \\
\hline Public Hospital & 21 & 51,2 \\
\hline SUS Outpatient Clinic & 17 & 41,5 \\
\hline Teaching Hospital & 11 & 26,8 \\
\hline
\end{tabular}

research quantitative results. The discursive analysis showed that $51.6 \%$ $(\mathrm{n}=32)$ of the statements fit the category "Dissatisfaction with the program's practical performance" and $43.55 \%(\mathrm{n}=27)$ referred to "Dissatisfaction with the program organization and coordination". The qualitative analysis results of the open questions are shown in Table 3.

The participants' notes showed the importance of using medical practice aimed at learning, with discussion of cases and stimulating clinical reasoning in an integrated and complex manner, essential instruments for the development of professional skills during medical residency. ${ }^{21}$ In a literature review, Botti ${ }^{21}$ states that the offer of assorted clinical opportunities, leading the learner to associate their knowledge to practice and avoiding automatism with training in cognitive attributes alone, are some of the most important tools for building quality clinical reasoning during MR. ${ }^{21}$

When asked about giving up during the MR, $41.5 \%(n=17)$ of the interviewees answered that they had thought about quitting (Table 2). This shows that many of the graduates faced difficulties that they considered significant enough to rethink their stay in the program. The qualitative analysis showed characteristics considered negative by the graduates, such as "Physical wear", with $57.14 \%(\mathrm{n}=16)$ of the observations considered the most important one. The increased number of hours spent on duty certainly has a negative impact on the resident. Emotional wear represented $25 \%(n=7)$ of the statements found for the question. Studies have shown that the residency program, in itself, is a source of tension and stress for the resident. ${ }^{22}$ The rates of burnout, depression, irritability and anxiety are higher among physicians during the residency period. ${ }^{23}$

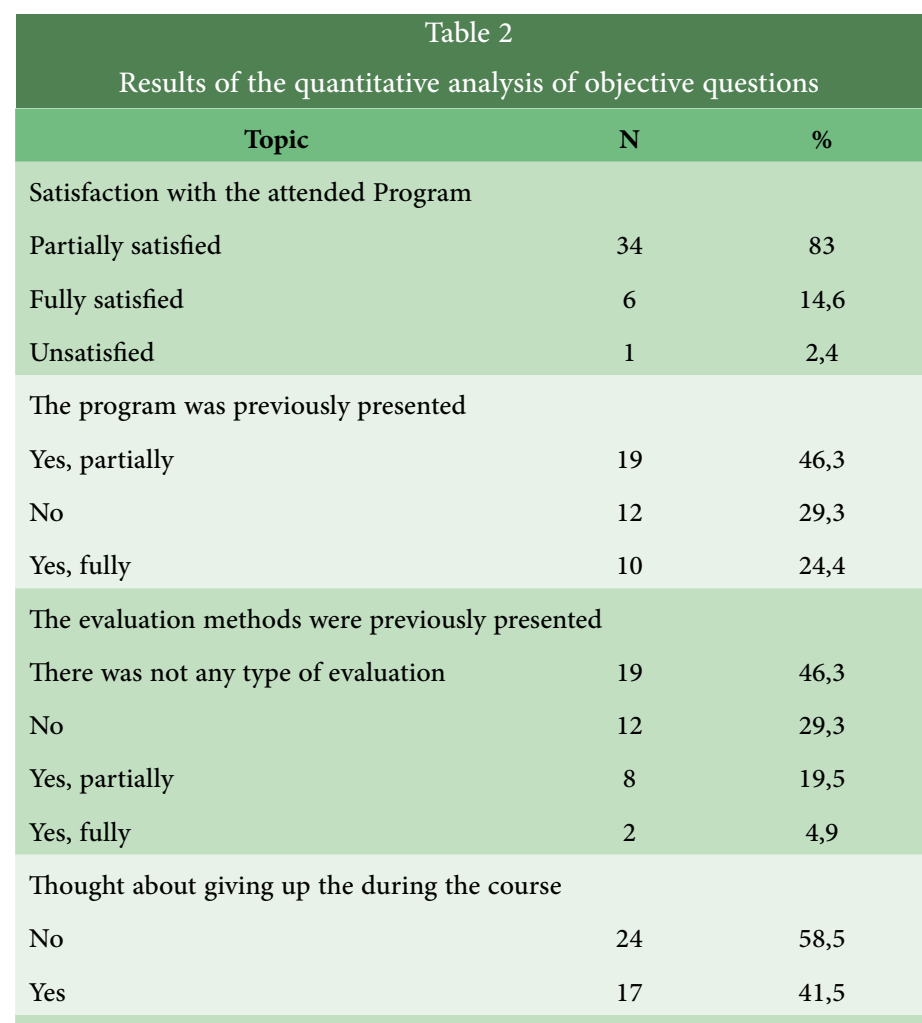

There was Preceptor / Teacher with the resident during a patient treatment

$\begin{array}{lcc}\text { Majority of times } & 23 & 56,1 \\ \text { Sometimes } & 14 & 34,1 \\ \text { Always } & 4 & 9,8\end{array}$

There was educational guidance during case discussion

Majority of times $23 \quad 56,1$

Sometimes $\quad 15 \quad 36,6$

$\begin{array}{lll}\text { Always } & 2 & 4,9\end{array}$

$\begin{array}{lll}\text { Never } & 1 & 2,4\end{array}$

There was a post-duty resting period

Sometimes $\quad 17 \quad 41,5$

Majority of times $11 \quad 26,7$

Never $\quad 9 \quad 22$

$\begin{array}{lll}\text { Always } & 4 & 9,8\end{array}$

There was a weekly theoretical activity during the course

Sometimes $\quad 17 \quad 41,5$

Always $14 \quad 34,1$

Majority of times $\quad 8 \quad 19,5$

Never $\quad 2 \quad 4,9$

The residents were participating in theoretical activities

$\begin{array}{lll}\text { Sometimes } & 19 & 46,3\end{array}$

Majority of times $\quad 18 \quad 43,9$

Always $\quad 2 \quad 4,9$

$\begin{array}{lll}\text { Never } & 2 & 4,9\end{array}$

Continue... 


\begin{tabular}{|c|c|c|}
\hline \multicolumn{3}{|c|}{ Continuation } \\
\hline Topic & $\mathbf{N}$ & $\%$ \\
\hline \multicolumn{3}{|c|}{ Avarege hours of weekly theoretical activity } \\
\hline $2 \mathrm{~h}$ & 17 & 41,5 \\
\hline $4 \mathrm{~h}$ & 10 & 24,4 \\
\hline $1 \mathrm{~h}$ & 7 & 17,1 \\
\hline $3 \mathrm{~h}$ & 5 & 12,1 \\
\hline $\mathrm{oh}$ & 2 & 4,9 \\
\hline
\end{tabular}

Were you offered learning opportunities with technologies that help diagnose/treat obstetrics \& gynecology pathologies

$\begin{array}{lcc}\text { Sometimes } & 33 & 80,5 \\ \text { Never } & 6 & 14,6 \\ \text { Majority of times } & 2 & 4,9 \\ \text { Always } & 0 & 0 \\ \text { Considered the number of obstetric procedures appropriate for learning } \\ \text { Yes } & 37 & 90,2 \\ \text { No } & 4 & 9,8\end{array}$

Considered the number of gynecological procedures appropriate for learning

$\begin{array}{lcc}\text { No } & 39 & 95,1 \\ \text { Yes } & 2 & 4,9 \\ \text { Had any incentive for Scientific researches during the program } & \\ \text { Never } & 22 & 53,6 \\ \text { Sometimes } & 17 & 41,5 \\ \text { Majority of times } & 2 & 4,9 \\ \text { Always } & 0 & 0\end{array}$

Had any article published in a journal during the Program

$\begin{array}{lcc}\text { No } & 38 & 92,7 \\ \text { Yes } & 3 & 7,3\end{array}$

Had any article published in a journal after finishing the Program

$\begin{array}{lcc}\text { No } & 34 & 82,9 \\ \text { Yes } & 7 & 17,1\end{array}$

Had any article/research presented in a scientific event during the Program

$\begin{array}{lll}\text { No } & 28 & 68,3 \\ \text { Yes } & 13 & 31,7\end{array}$

Had any article/research presented in a scientific event after finishing the program

No

$32 \quad 78$

Yes

922

\begin{tabular}{|c|c|c|}
\hline $\begin{array}{c}\text { Table } 3 \\
\text { Qualitative analysis of the questionnaire c }\end{array}$ & cursive respor & \\
\hline Categories to each topic & $\begin{array}{l}\text { Number of } \\
\text { affirmations }\end{array}$ & $\%$ \\
\hline Satisfaction with the attended Program & & \\
\hline $\begin{array}{l}\text { Dissatisfaction with the program's practical } \\
\text { performance }\end{array}$ & 32 & 51,61 \\
\hline $\begin{array}{l}\text { Dissatisfaction with the program's organization } \\
\text { and coordination }\end{array}$ & 27 & 43,55 \\
\hline Fully satisfied with the residency training & 3 & 4,84 \\
\hline Reasons for thinking about leaving the program & & \\
\hline Physical stress & 16 & 57,14 \\
\hline Emotional stress & 7 & 25 \\
\hline $\begin{array}{l}\text { Incompatibility between expectations and the } \\
\text { reality found }\end{array}$ & 5 & 17,86 \\
\hline Presence of a Preceptor / Teacher with the resident $d$ & ing a patient tre & tment \\
\hline $\begin{array}{l}\text { No monitoring during medical treatment, giving } \\
\text { autonomy to the resident }\end{array}$ & 9 & 42,86 \\
\hline $\begin{array}{l}\text { Medical treatment monitored only by the oldest } \\
\text { resident }\end{array}$ & 6 & 28,57 \\
\hline $\begin{array}{l}\text { Present in most activities, except at the on-call } \\
\text { shifts }\end{array}$ & 3 & 14,29 \\
\hline $\begin{array}{l}\text { Present in most activities, except at the outpatient } \\
\text { clinics }\end{array}$ & 3 & 14,29 \\
\hline
\end{tabular}

Educational guidance during case discussion with the Teacher / Preceptor

Focus of the discussion was only for resolution of $\quad 5 \quad 62,5$ the shift

Opportunity made available only by a few teachers/preceptors

Participation or not of residents in theoretical activities

Forbidden by the preceptors / On-call chiefs $\quad 16 \quad 80$

Lack of interest in the class topic by the resident $\quad 3 \quad 15$

Hierarchical position

15

Were you offered learning opportunities with technologies that help diagnose/treat obstetrics \& gynecology pathologies

Poor structure of the program / hospital for the activities

Limited material availability for these activities $\quad 5 \quad 26,32$

$\begin{array}{lll}\text { Poor faculty availability for these activities } & 2 & 10,53\end{array}$

Reasons for considering surgical procedures as appropriate or inappropriate for learning during the Program

Few training opportunities in the Program schedule $\quad 25 \quad 62,5$

$\begin{array}{lll}\text { Surgical cancellations } & 11 & 27,5\end{array}$

Small number of Teachers / Preceptors available
for these activities

for these activities

Reasons for the frequency of scientific research stimulation during the Program found

Lack of encouragement from Preceptors / Teachers $\quad 5 \quad 83,33$

$\begin{array}{lll}\text { The interest always came from the resident } & 1 & 16,67\end{array}$ 


\begin{tabular}{|c|c|c|}
\hline $\begin{array}{c}\text { Table } 3 \\
\text { Continuation }\end{array}$ & & \\
\hline Categories to each topic & $\begin{array}{l}\text { Number of } \\
\text { affirmations }\end{array}$ & $\%$ \\
\hline R1 Strengths & & \\
\hline Delivery care & 35 & 70 \\
\hline Large volume of patient care & 12 & 24 \\
\hline Good learning in urgency and emergency & 3 & 6 \\
\hline R2 Strengths & & \\
\hline Learning in Obstetric subspecialties & 25 & 48,08 \\
\hline Personal and professional development & 9 & 17,31 \\
\hline Learning in Gynecology subspecialties & 6 & 11,54 \\
\hline Workload reduction in comparison to the previous year & 5 & 9,62 \\
\hline Surgical Learning & 4 & 7,69 \\
\hline There were no strengths to be mentioned & 3 & 5,77 \\
\hline R3 Strengths & & \\
\hline Middle and High-complexity surgical procedures & 20 & 35,71 \\
\hline Obstetric practice & 13 & 23,21 \\
\hline Subspecialty practice in Obstetrics and Gynecology & 12 & 21,43 \\
\hline Personal and professional development & 6 & 10,71 \\
\hline There were no strengths to be mentioned & 3 & 5,36 \\
\hline $\begin{array}{l}\text { Workload reduction in comparison to the previous } \\
\text { year }\end{array}$ & 2 & 3,57 \\
\hline R1 weaknesses & & \\
\hline $\begin{array}{l}\text { Lack of monitoring, supervision and guidance by } \\
\text { preceptorship / faculty }\end{array}$ & 17 & 26,15 \\
\hline Little dedication to theoretical support during the year & 14 & 21,54 \\
\hline $\begin{array}{l}\text { Physical and emotional stress due to amount of } \\
\text { workload }\end{array}$ & 13 & 20 \\
\hline Lack of practice in ambulatory gynecology & 12 & 18,46 \\
\hline Lack of active participation in surgical procedures & 6 & 9,23 \\
\hline Lack of obstetric practice in primary care & 2 & 3,08 \\
\hline There were no strengths to be mentioned & 1 & 1,54 \\
\hline R2 weaknesses & & \\
\hline Little surgical practice & 26 & 43,33 \\
\hline Little gynecolgy practice & 12 & 20 \\
\hline Little dedication to theoretical support during the year & 11 & 18,33 \\
\hline $\begin{array}{l}\text { Lack of organization, supervision and guidance by } \\
\text { the preceptorship / faculty }\end{array}$ & 6 & 10 \\
\hline Little practice in low-risk activities & 4 & 6,67 \\
\hline There were no strengths to be mentioned & 1 & 1,67 \\
\hline
\end{tabular}

Continue...

\begin{tabular}{|c|c|c|}
\hline \multicolumn{3}{|l|}{$\begin{array}{c}\text { Table } 3 \\
\text { Continuation }\end{array}$} \\
\hline Categories to each topic & $\begin{array}{l}\text { Number of } \\
\text { affirmations }\end{array}$ & $\%$ \\
\hline \multicolumn{3}{|l|}{ R3 weaknesses } \\
\hline Little surgical practice & 19 & 32,76 \\
\hline Little gynecolgy practice & 15 & 25,86 \\
\hline Lack of organization of the program's schedule & 9 & 15,52 \\
\hline Little dedication to theoretical support during the year & 8 & 13,79 \\
\hline $\begin{array}{l}\text { Lack of supervision and guidance by the } \\
\text { preceptorship / faculty }\end{array}$ & 7 & 12,07 \\
\hline \multicolumn{3}{|l|}{ Improvement suggestions given by the participants } \\
\hline Improve the program structure and organization & 59 & 45,38 \\
\hline $\begin{array}{l}\text { Add educational planning with emphasis on } \\
\text { learning for each year }\end{array}$ & 26 & 20 \\
\hline $\begin{array}{l}\text { Increase stimulation and scientific production with } \\
\text { the participation of teachers, preceptors, residents } \\
\text { and students }\end{array}$ & 21 & 16,15 \\
\hline $\begin{array}{l}\text { Pedagogical training and updating of the preceptorship / } \\
\text { faculty working in the services of the program }\end{array}$ & 15 & 11,54 \\
\hline $\begin{array}{l}\text { Incorporating constructive feedback and } \\
\text { assessment techniques }\end{array}$ & 7 & 5,38 \\
\hline No suggestions for change & 2 & 1,54 \\
\hline
\end{tabular}

The term "Moral harassment" recorded by participant number 11 deserves to be highlighted. Despite the infrequent result, evidence shows that moral harassment is commonly found in the hospital environment and in MR programs. ${ }^{24}$ If there was a specific question about harassment during the course in this research, it would be possible to verify a higher number than the one found. Its definition is difficult due to possible interpretations of a great diversity of abusive acts and behaviors. Moral harassment often occurs in closed institutional settings, with an asymmetric hierarchical prevalence, where its actions are commonly carried out in silence. ${ }^{24,25}$ And, considering the MR environment, this silencing occurs in both actors (abuser and abused).

The interest of the trainee physicians in ensuring greater opportunities for practice and better teaching by their tutors places them in a situation of greater vulnerability, and they may be susceptible to abusive actions and conduct them in a reserved manner, in order to preserve their learning. This can have an impact on the professional's future, as shown by evidence proving the greater tendency to psychiatric disorders and patient abuse among those harassed professionals. ${ }^{25}$ On other occasions, the feeling of having the obligation to present themselves as infallible professionals can cause feelings such as frustration and anguish to the preceptor, which are often projected during the teaching process, camouflaged as demands and criticisms to the resident. ${ }^{25}$ The mechanisms involved in abusive relationships in the medical environment and, especially in MR, are certainly more extensive, and a deeper assessment of these mechanisms is of the utmost importance. ${ }^{25}$

The questions about the program structure and organization showed that the lack of prior formal program presentation, either partial or in full, 
recorded an accumulated percentage of $75.5 \%(n=31)$ of the interviewees (Table 2). Not offering the possibility for the residents to know, understand and clarify doubts about the program can generate feelings such as anguish, fear and frustration, impacting their performance and quality of life. ${ }^{26}$ Almost half $(41.5 \%, n=17)$ of the graduates said they had rested after the on-duty shift a few times. A possible explanation for this finding is the fact that the norm was considered mandatory as of its publication, in $2011^{27}$, and this result can be attributed to the participants who attended the program before this date. Moreover, possible replacements of residents who leave gaps in care activities could have been a reason why graduates failed to fulfill their rest hours.

A large majority ( $n=33,80.5 \%)$ reported having received training with auxiliary technologies in the diagnosis and treatment of diseases in GO, such as ultrasound, hysteroscopy and stereotaxy, only a few times. The qualitative analysis showed a prevalence $(63.16 \%, \mathrm{n}=12)$ of discursive responses for "Deficient structuring of the program for the activities" (Table 3). The transcribed response: "We had no internship program for these types of exams. Only in R3 we followed breast biopsies, for example." (Participant N. 20) exemplifies the structural difficulty. Because they are increasingly more frequent in the routine of large services, especially in high-complexity teaching hospitals, the basic teaching of these technologies is necessary, especially regarding theoretical knowledge. It is after this initial contact that the physician, after completing the specialization, can choose to go deeper into specific training that adds knowledge to their training, such as lato sensu courses proposed by some institutions. ${ }^{28}$

When assessing whether the number of surgical procedures was adequate for their training, it was found that $90.2 \%(\mathrm{n}=37)$ considered it appropriate only for obstetric ones. The majority $(n=39,95.1 \%)$ revealed an inappropriate frequency of gynecological surgeries for learning (Table 2). When analyzing the justifications for this question, it was observed that $62.5 \%(n=25)$ refer to "Few training opportunities in the program's schedule" (Table 3). This result gains strength when compared to the findings in the comparative analysis of the distribution of activities, confirming the statement. In addition to "Surgical impediments" (27.5\%, $n=11)$, the two justifications accumulate 90\% $(\mathrm{n}=36)$ of the statements. The transcribed phrase "Little workload in gynecology surgery. Surgery cancellations were frequent." (Participant N. 23) shows the reality faced by the majority.

When asked about their evaluation of the residency, almost half of respondents $(n=19,46.3 \%)$ said they did not have any type of assessment during the course. A possible justification for this result would be the residents' lack of knowledge about the instruments used by the program, described in the regulation, and the fact they may have been submitted to evaluation (of frequency or behavior and attitude) without realizing it. Another possible explanation would be the scarcity of qualified professionals, especially among field preceptors, who are not always motivated or trained to carry out evaluation processes with feedback.

The large number of hours on duty in the program means that the onduty professional often acts as a preceptor and, despite having specialized professional training and experience in the practice of medicine, they do not have the pedagogical knowledge necessary to adequately perform supervisory, correction, teaching and evaluation tasks of the resident physician. The lack of preparedness for the functions, added to the lack of communication and supervision by the institution, make the teachinglearning process outdated and devalued. ${ }^{29,30}$
It is understandable to note that the majority of the 30 respondents who answered they had been evaluated had neither summative $(n=27$, $90 \%)$ nor formative ( $\mathrm{n}=21,70 \%)$ evaluations, since the program does not require other evaluation methods in addition to attitudinal performance and frequency. Another important result is found in the question about feedback, which demonstrated significant fragility, after revealing that $83 \%(n=25)$ of those who answered they had been evaluated did not have any type of feedback.

The importance of the presence of evaluation in the development of skills and knowledge is well known. ${ }^{29,30}$ What should be reflected on are the assessment methods used in MR programs today. It is necessary to know the advantages and disadvantages of the different methods ${ }^{30}$ to use the most adequate one for each skill to be evaluated. According to Nunes et al. ${ }^{31}$, the resident must be evaluated in a multidimensional way, from knowledge and practical performance to the ability to communicate/relate with patients; knowing how to work as a team; with responsibility, ethics, social commitment and in accordance with health policies. ${ }^{30}$

When assessing the practice, $56.1 \%$ of the graduates $(n=23)$ considered that the monitoring by a teacher or preceptor during medical care happened most of the times. The qualitative analysis showed that 42.86\% ( $n=9)$ of the statements comprise the category "Care without monitoring, giving autonomy to the resident," followed by "Care accompanied only by the oldest resident," with $28.57 \%(n=5)$ of the observations. It is possible to perceive the strength of the hierarchy in the medical practice environment in this program, being evident both by its rules and by the graduates' clippings, as follows:

"In R1, which is when we are learning, the closest to us is the R2. The boss is often made inaccessible with the excuse of hierarchy and, thus goes the first and most important year of specialist training." (Participant N.19)

It was found that $56.1 \%(\mathrm{n}=23)$ of the participants stated that educational guidance, during medical care, occurred most of the time and $36.6 \%(n=15)$ reported a lower frequency (sometimes). Most of the justifications ( $n=5,62.5 \%)$ were included in the category "Focus of the discussion was only on the progress of the service". Evidence shows that the great demands for care and workload are the main obstacles faced by teachers in a MR program. ${ }^{31}$ These aspects, added to the low acknowledgement of the profession, with consequent low remuneration, precarious working conditions, and constant challenge in arousing the curiosity and interest in the trainee culminate in disappointments in the exercise of the profession that discourage the professional. ${ }^{31}$

When analyzing the frequency of theoretical activities, it was found that $41.5 \%(n=17)$ of the interviewees considered that they happened only a few times (Table 2 ). When asked whether graduates participated in theoretical activities, $46.3 \%(n=19)$ answered yes, sometimes.

The discursive analysis for the justification disclosed a predominance ( $n=16,80 \%)$ of the observations for "Prohibition of teaching/ preceptorship" (Table 3). Therefore, it can be observed that the theoretical activities come second, being carried out on special occasions (permission from the preceptorship/faculty, subject of interest for the resident and favorable hierarchical position). It is understood that the essence of the MR program is the practical action, but one must remember the importance of associating theory with exercise as the basis for improving clinical reasoning and medical expertise. ${ }^{21}$ This analysis makes it understandable the variety of weekly workloads found among the interviewees (Table 2).

REVISTA BRASILEIRA DE EDUCAÇÃO MÉDICA

$944(2): \mathrm{e} 057 ; 2020$ 
When assessing the stimulus to scientific production during the program, $53.7 \%$ ( $n=22$ ) of the interviewees reported it was null ("never"). In a cross-analysis with data obtained in "academic degree," there was no significance $(p=0.107)$. However, it is possible to notice a certain tendency, among those graduates whose stimulus to conduct research was reduced or nonexistent, to not progress to other specialists' titles. The discursive analysis revealed that only one observation (16.67\%) mentioned the resident's interest as a factor that caused little stimulus to research, and $83.33 \%(n=5)$ referred to the category "Little stimulus on the part of preceptors/teachers" (Table 3 ).

The low number of discursive answers to this question made it difficult to discuss them; however, related studies ${ }^{32,33}$ show discouraging factors for academic practice, such as bureaucratic issues related to research, insufficient research training time and financial issues. Among the factors that were important in the choice of academic career are the admiration for the professors-advisors, the teaching experiences lived with the medical students and having presented works at scientific events. Knowing the factors that can stimulate and limit medical practice in research during residency is an important strategy to strengthen the scientific environment of an institution ${ }^{32,33}$ despite the questionable period during MR as being ideal for scientific work practice, considering the great demand for specialized technical learning required from the resident, especially in the first year of the program.

The vast majority of graduates did not publish any scientific articles in a journal during $(n=38,92.7 \%)$ or after the end of the program $(n=$ $34,82.9 \%)$. Similar results were found for the presentation of scientific papers at events in the area (Table 2). These data can indicate the profile of the professional trained by this program, being more focused on the job market than on research.

The qualitative results on the strengths of the program revealed that obstetric activities have great relevance for learning during the three years of MR. Despite negative statements about excessive on-duty hours and its consequences, this characteristic was used by the graduates, so that the intense obstetric practice became the main strength of the program (Table 3). Learning in subspecialties is valued in R2 and R3, as well as personal and professional development. There is good use of the activities in the operating room in the third year $(35.71 \%)$, even though the workload is considered lower than that proposed by CNRM (Table 3 ).

The weaknesses most frequently pointed out by the graduates were "Lack of follow-up, supervision and guidance by the preceptor/teacher" in $\mathrm{R} 1$, and statements about "Little surgical practice" and "Little practice in outpatient gynecology" were more evident in the last two years. It was also observed a lower percentage, however relevant, for the categories "Lack of organization of the program schedule," "Little dedication to theoretical support during the year" and "Lack of supervision and guidance of the preceptorship/faculty" in R3. These three categories are related to the main activities assigned to the program coordination. These results disclose an important structural diagnosis of the program and can be used as a guide for possible adjustments in the future.

The analysis of the discursive responses on suggestions for change (Table 3 ) showed that $45.38 \%(n=59)$ of the observations were related to "Improving program structure and organization". The differences found in the workload arrangement for the activities of each year, as compared to that proposed by CNRM, and the extensive on-duty workload observed in the first and second years are in line with these findings and reflect administrative obstacles. In "Educational planning with emphasis on learning for each year" ( $n=26,20 \%)$ there were suggestions that referred to the appreciation of the resident's learning above the service progress such as the transcript: "Better distributed hours, theoretical classes, evaluation tests, more present staff and interested in contributing to teaching". (Participant N. 31).

With these statements, graduates try to show the importance of educational dedication in their training and how it has been neglected in some way during their experience in the program. The category "Increase stimulation and scientific production with the joint participation of teachers, preceptors, residents and students", with $16.15 \%(n=21)$ of the observations, shows that although the majority of the interviewees did not present scientific productions, these activities are considered important. The "Pedagogical training and updating of the preceptorship that works in the services included in the program" accumulated $11.54 \%(n=15)$ of the observations and constitutes a fundamental strategy for the best success in the resident teaching-learning process. Providing adequate tools for the transmission of knowledge and practical training, important for an educator, increases the likelihood of success in the development and acquisition of medical expertise in the specialty. ${ }^{31,21}$

\section{CONCLUSIONS}

The comparative analysis of the distribution of activities allowed a better mapping of the assessed Program, showing positive characteristics, such as the presence of an elective training and dedication to studies on care protocols. However, there are aspects that are potentially harmful to learning, such as excessive on-duty hours and deficits in hours dedicated to certain activities, such as a surgical center and a specialty outpatient clinic. The suggestion is that some topics be revised, such as redistributing the workload and instituting evaluations for students and educators, so that improvements in the quality of teaching and specialist training can be achieved.

Although the percentage of respondents (66\%) made it possible to validate the results, we recognize that the number of participants who answered the questionnaire (41) was a limiting factor for the acquisition of even more significant results, mainly for obtaining cross-data. It was possible to reflect on aspects that impact the training of specialists. Perhaps larger studies can bring more information to further the discussion about aspects that cause positive and negative impressions on graduates, such as relationships between colleagues, educators, health service employees and their patients, as well as on medical, ethical and legal challenges brought on by the specialty.

The absence of an analysis and discussion on whether or not to acquire the title of specialist provided by the Brazilian Federation of Gynecology and Obstetrics (FEBRASGO), as well as information on performance, pass and fail rates, represents a limitation of this study as these data could possibly provide additional information on the graduate's professional profile. As the exam is acknowledged at a national level and has a large repertoire of evaluations over the years, its data could potentially provide subsidies that would guide the creation of strategies to improve women's health care, in addition to assisting in the search for improvement in the teaching of residency programs.

Based on the findings, suggestions for changes were proposed and

$10 \mid$\begin{tabular}{l|l} 
REVISTA BRASILEIRA DE EDUCAÇÃO MÉDICA \\
\hline 4 (2) : e057; 2020
\end{tabular} 
accepted by the managers, which should have a positive impact on the residency teaching. This research contributes to the diagnostic evaluation of a traditional medical residency program, proposes improvements and uses a reproducible methodology; therefore, it can be used as a comparison for others, so that advances can be established in the training of specialists.

\section{ACKNOWLEDGMENTS}

To all those who, in some way, contributed to this work, I express my gratitude, especially to Cibele Isaac Saad Rodrigues.

\section{REFERENCES}

1. Martins LAN. Residência médica: estresse e crescimento. São Paulo: Casa do Psicólogo; 2005.

2. Miranda Júnior UJP. Comissão Nacional de Residência Médica: caminhos e descaminhos na gestão desta modalidade de especialização médica no Brasil [dissertação]. Rio de Janeiro: Fundação Getulio Vargas; 1997.

3. Michel JLM, Oliveira RAB, Nunes MPT. Residência médica no Brasil. Cad ABEM 2011;7:7-12.

4. Brasil. Decreto $n^{\circ} 91.364$, de 21 de junho de 1985. Altera a redação do $\$ 1^{\circ}$ do artigo $2^{\circ}$ do Decreto no 80.281/77, que dispõe sobre a constituição da Comissão Nacional de Residência Médica. Diário Oficial da União 22 jun1985; Seção 1, p. 8793 [acesso em 12 nov 2019]. Disponível em: https://www.infectologia.org.br/admin/ zcloud/89/2016/06/d91364.pdf.

5. Brasil. Ministério da Educação e Cultura. Secretaria de Educação Superior. Comissão Nacional de Residência Médica. Resolução ${ }^{\circ}$ 5, de 12 de novembro de 1979. Estabelece normas, duração e carga horária dos programas [acesso em 12 set 2018]. Disponível em: http:// portal.mec.gov.br/sesu/arquivos/pdf/CNRM0579.pdf.

6. Brasil. Lei no 6.932, de 7 de julho de 1981. Dispõe sobre as atividades do médico residente, e dá outras providências. Diário Oficial da União 9 jul 1981; Seção 1, p. 12789.

7. Ribeiro MAA. Apontamentos sobre residência médica no Brasil. Brasília: Câmara dos Deputados, Consultoria Legislativa; 2011. [acesso em 12 set 2018] Disponível em: https://www2.camara.leg. br/atividade-legislativa/estudos-e-notas-tecnicas/publicacoes-daconsultoria-legislativa/areas-da-conle/tema11/2011_123.pdf.

8. Silva P. Saúde financia mais de 1.370 novas bolsas de residência médica. Ministério da Saúde, 15 mar 2016 [acesso em 1ºvev 2018]. Disponível em: http://www.saude.gov.br/noticias/agencia-saude/22637-saudefinancia-mais-1-370-novas-bolsas-de-residencia-medica.

9. Michel JLM, Junior AL, Santos RA, Oliveira RAB, Rebelatto JR, Nunes NPT. Residência médica no Brasil: panorama geral das especialidades e áreas de atuação reconhecidas, situação de financiamento público e vagas oferecidas. Cad ABEM 2011;7:13-27. [acesso em 12 set 2018] Disponível em: https://website.abem-educmed.org.br/wp-content/ uploads/2019/09/CadernosABEM__Vol07.pdf.

10. Nunes MPT, Michel JLM, Haddad E, Brenelli SL, Haddad DM, Ribeiro ECO, et al. Distribuição de vagas de residência médica e de médicos nas regiões do país. Cad ABEM 2011;7:28-34. [acesso em 12 set 2018] Disponível em: https://website.abem-educmed.org.br/wpcontent/uploads/2019/09/CadernosABEM_Vol07.pdf.
11. Sistema Eletrônico do Serviço de Informações ao Cidadão [acesso em 12 set 2018]. Disponível em: https://esic.cgu.gov.br/sistema/site/index.aspx

12. Brasil. Comissão Nacional de Residência Médica. Resolução $\mathrm{n}^{\circ}$ 2, de 17 de maio de 2006. Dispõe sobre requisitos mínimos dos Programas de Residência Médica e dá outras providências [acesso em 8 nov 2018]. Disponível em: http://portal.mec.gov.br/dmdocuments/ resolucao02_2006.pdf.

13. Pontifícia Universidade Católica de São Paulo. Faculdade de Ciências Médicas e da Saúde. COREME. Regulamento da Residência Médica de Ginecologia e Obstetrícia. Sorocaba: PUC-SP, FCMS, Coreme; 2016.

14. Cochran WG. Sampling techniques. 3rd ed. New York: John Wiley; 1977.

15. Bardin L. Análise de conteúdo. São Paulo: Edições 70; 2011.

16. Carlomango MC, Rocha LC. Como criar e classificar categorias para fazer análise de conteúdo: uma questão metodológica. Rev. eletrôn. ciênc. pol. 2016;7(1)173-88.

17. Brasil. Ministério da Educação. Proposição de Conteúdo dos Programas de Residência Médica (Resolução ${ }^{\circ}$ 2, de 17 de maio de 2006) [acesso em 10 set 2018]. Disponível em: https://abhheventos.com.br/forum2017/ wp-content/uploads/2016/12/projeto-conteudos2.pdf.

18. Hamamoto Filho PT, Oliveira CC, Silva LA, De Carvalho LR, Peraçoli JC, Borges VTM. Feedback de usuários como subsídio para avaliação do estudante de medicina. Rev. bras. educ. med. 2012;36(3)381-86.

19. Botti SHO, Rego STA. Docente-clínico: o complexo papel do preceptor na residência médica. Physis (Rio J.) 2011;21(1):65-85.

20. Liu GKH, De Pontes MVCG, Silva KV, Mandia TM, de Sá BL, Valladão Júnior JBR. Experiências com estágios externos na Residência de Medicina de Família e Comunidade da Faculdade de Medicina da Universidade de São Paulo. Rev. bras. med. fam. comunidade 2018;13(40):1-7.

21. Botti SH, Rego S. Processo ensino-aprendizagem na residência. Rev. bras. educ. med. 2010;34(1):132-40.

22. Coeck C, Jorens PG, Vandevivere J, Mahler C. ACTH and cortisol levels during residency training. N. Engl. j. med.1991;325(10)738.

23. Levey RE. Sources of stress for residents and recommendations for programs to assist them. Acad. med. 2001;76(2):142-50.

24. Marques RC, Martins Filho ED, De Paula GS, Dos Santos RR. Assédio moral nas residências médica e não médica de um hospital de ensino. Rev. bras. educ. med. 2012;36(3):401-6.

25. Conselho Regional de Medicina do Estado de São Paulo. Assédio moral. São Paulo: Cremesp; 2017 [acesso em $12 \mathrm{dez}$ 2018]. Disponível em: http://www.cremesp.org.br/pdfs/CARTILHA-Assedio-Moral-p5.pdf.

26. Richman JA, Flaherty JA, Rospenda KM, Christensen ML. Mental health consequences and correlates of reported medical student abuse. JAMA 1992;267(5):692-4.

27. Brasil. Comissão Nacional de Residência Médica. Resolução $\mathrm{n}^{\circ} 1$, de 16 de junho de 2011. Dispõe sobre o estabelecimento e condições de descanso obrigatório para o residente que tenha cumprido plantão noturno [acesso em 21 nov 2018]. Disponível em: http://portal.mec.gov. br/index.php?option $=$ com_docman\&view $=$ download\&alias $=8948$-res cnrm-01-2011-1\&category_slug=setembro-2011-pdf\&Itemid=30192.

28. Barrozo SG, Rangel M, Barrozo PRM, Lasmar RB, Oliveira MAP, Dias R. Uma proposta para ensino de videoendoscopia ginecológica em nível de pós-graduação. Femina 2005;33(6):423-7.

29. Borges MC, Miranda CH, Santana RC, Bollela VR. Avaliação formativa e

$11 \mid$\begin{tabular}{l|l} 
REVISTA BRASILEIRA DE EDUCAÇÃO MÉDICA \\
44 (2) : e057; 2020
\end{tabular} 
feedback como ferramenta de aprendizado na formação de profissionais da saúde. Medicina (Ribeirão Preto) 2014;47(3):324-31.

30. Nunes MPT, Martins ACS, Machado VR. Avaliação do Sistema RM: instituição, programa, residente, corpo docente. Cad ABEM 2011;7:41-56.

31. Nunes MPT, Michel JLM, Haddad AE, Brenelli SL, Oliveira RAB. A residência médica, a preceptoria, a supervisão e a coordenação. Cad ABEM 2011;7:35-40.

32. Meurer GH, Kozuki H, De Oliveira Filho GR. Avaliação do interesse na carreira acadêmica dos médicos em especialização em anestesiologia. Rev. bras. anestesiol. 2010;60(6):567-76.

33. Reck SJ, Stratman EJ, Vogel C, Mukesh BN. Assessment of residents' loss of interest in academic careers and identification of correctable factors. Arch. dermatol. 2006;142(7):855-8.

\section{AUTHORS' CONTRIBUTION}

Study Conception and design: Natalia Romano Sanchez, Cibele Isaac Saad Rodrigues
Data Analysis and interpretation: Natalia Romano Sanchez, Cibele Isaac Saad Rodrigues

Data collection: Natalia Romano Sanchez

Writing of the manuscript: Natalia Romano Sanchez Cibele Isaac Saad Rodrigues

Article critical review: Cibele Isaac Saad Rodrigues

Article final approval: Cibele Isaac Saad Rodrigues

Statistical analysis: Natalia Romano Sanchez, Cibele Isaac Saad Rodrigues

General responsibility for the study: Natalia Romano Sanchez

All authors have read and approved the final version.

\section{CONFLICT OF INTERESTS}

The authors declare no conflicts of interest.

\section{ADDRESS FOR CORRESPONDENCE}

Natalia Romano Sanchez.

Rua Capitão Grandino, 380/1104, Sorocaba, São Paulo, SP, Brasil. CEP: 18040-560.

E-mail: nataliasanchez.med@gmail.com 